\title{
KEADILAN GENDER DALAM HUKUM PEMBAGIAN WARIS ISLAM PERSPEKTIF THE THEORY OF LIMIT MUHAMMAD SYAHRUR
}

\author{
Muhammad Ali Murtadlo \\ Awardee LPDP RI di UIN Maulana Malik Ibrahim Malang, Indonesia \\ E-mail: aldo.murtadlo@gmail.com
}

\begin{abstract}
The division of inheritance it refers to the verses of inheritance turns out to date still leaves unresolved problems, such as the 2: 1 division between men and women who are considered gender biased. According Syahrur, inheritance legislation is time to change. Syahrur uses various methods in studying Islamic inheritance law, such as mathematical theory with reference to Newton's mathematical analysis theory. By the method of mathematical analysis, Syahrur formulated the boundaries of Allah's law which is termed with The Theory Of Limit. In this theory, there is an understanding of the limits of Allah's provisions that should not be violated, but within it there is a flexible area of ijtihad. According to him, QS. AnNisa 'verse 11 which explains the male's doubling part is the maximum and can not be added, while the woman is the minimum limit, so under certain circumstances a woman potentially has more share. The Limit Theory intends to state that the Qur'anic verse, always relevant to every situation and condition, and Islam is the last and universal religion directed to all mankind.
\end{abstract}

Keywords: Gender Justice, Inheritance, Theory of Limit, Muhammad Syahrur.

\section{Pendahuluan}

Problematika perempuan sudah muncul sejak masa Rasulullah. Fakta menunjukkan perempuan pada masa pra-Islam sudah mengalami berbagai praktik diskriminasi. Salah satu contohnya adalah dalam pembagian warisan. Perempuan dianggap tidak layak menerima harta warisan dan tidak termasuk dalam golongan ahli waris. Karena yang berhak atas harta warisan adalah laki-laki an sich. Hingga pada perkembangan selanjutnya, Islam sebagai agama rabmatan lil 'âlamîn hadir dengan membawa angin segar terhadap hak-hak perempuan serta mengangkat harkat dan martabatnya hingga setara dengan kaum laki-laki. 
Islam memandang laki-laki dan perempuan sebagai dua mahluk yang setara ${ }^{1}$, demikianlah yang disebutkan di dalam Al-Qur'an. Meskipun demikian, secara tekstual Al-Qur'an juga menyatakan adanya superioritas laki-laki atas perempuan, seperti dalam pembagian harta warisan. Laki-laki mendapatkan bagian yang lebih banyak dibandingkan yang diterima oleh perempuan dengan komposisi pembagian 1: 2 . Pembagian yang didapat anak laki-laki adalah dua kali lipat dari anak perempuan. Hal ini disebabkan adanya tanggung jawab yang lebih besar yang dibebankan kepada laki-laki, maka pantaslah dan adillah jika pembagian yang diperolehnya lebih banyak, sehingga hukum pembagian warisan dalam Islam tidak perlu diadakan perubahan karena sudah sesuai dan sejalan dengan konsep keadilan gender. ${ }^{2}$

Akan tetapi, zaman telah berubah dengan segala kemajuannya. Dampak kapitalisme dan industri modern agaknnya membuka kesempatan baru bagi perempuan untuk dapat berkiprah di luar rumah. Sehingga peran antara perempuan dan laki-laki hampir sama, khususnya dalam menjalankan roda perekonomian keluarga. Pergeseran peran lakilaki dan perempuan inilah yang menjadi isu gender di masyarakat. Perempuan yang dahulu hanya diposisikan sebagai konco winking (teman belakang), kini tidak sedikit yang bahkan menjadi tulang punggung perekonomian keluarga. Sehingga dengan banyaknya peran dan aktivitas perempuan di luar rumah, baik bekerja maupun keikutsertaan pada lembaga masyarakat, mempengaruhi pola kehidupannya, termasuk tuntutan dalam pembagian harta warisan.

Aktivis gender maupun kaum feminis selalu meminta kedudukan yang setara dengan laki-laki, sebab pada prinsipnya hukum menjunjung tinggi nilai keadilan yang sama rata, tanpa membedakan jenis kelamin. Hukum kewarisan Islam yang digagas para ulama Salaf kini tengah diuji oleh realitas sosial. Di satu sisi, ketentuan hukum kewarisan Islam yang termaktub dalam Al-Qur'an dan Hadis dianggap sebagai ketetapan yang bersifat qat'厃̂ dan final. Sementara di sisi lain, problem realitas kewarisan selalu muncul seiring berkembangnya peradaban manusia. Akibatnya, hukum kewarisan Islam klasik yang tekstualis tidak lagi mampu menjawab secara relevan dan rekonstruktif pelbagai persoalan yang

\footnotetext{
${ }^{1}$ QS. Al-Hujurat: 13

2 Gender berasal dari bahas Inggris “gender” yang berarti jenis kelamin. Secara umum gender digunakan untuk mengidentifikasi perbedaan laki-laki dan perempuan dari segi sosial budaya. Sementara seks secara umum mengidentifikasi perbedaan laki dan perempuan dari sisi anatomi biologis. Lihat Nasarudin Umar, Argumen Kesetaraan Jender, (Jakarta: Paramadina, 2001), 33.
} 
kompleks di era modern ini. Ketidakmampuan ini disebabkan ketidaksesuaian paradigma, metodologi, dan konsep (pemahaman teks Al-Qur'an dan Sunah) kewarisan produk ulama klasik dengan kondisi masa kini. ${ }^{3}$

\section{Pengertian Kewarisan Islam}

Kata waris berasal dari bahasa Arab, yaitu waritha-yarithu dan mirath (masdar), yang menurut bahasa berarti berpindahnya sesuatu dari seseorang kepada orang lain, atau dari suatu kaum kepada kaum lain. ${ }^{4}$ Pengertian menurut bahasa ini tidaklah terbatas hanya pada hal-hal yang berkaitan dengan harta, tetapi mencakup harta benda dan non harta benda. Sedangkan arti mîrath menurut istilah yang dikenal para ulama ialah berpindahnya hak kepemilikan dari orang yang meninggal kepada ahli warisnya yang masih hidup, baik yang ditinggalkan itu berupa harta (uang), tanah, atau apa saja yang berupa hak milik legal secara syar'i.

Sedangkan pengertian kewarisan menurut Muhammad Syarbini alKhatib sebagaimana dikutip oleh Ahmad Rofiq adalah hukum yang mengatur pembagian warisan dan mengetahui bagian-bagian yang diterima dari harta peninggalan untuk setiap yang berhak. ${ }^{5}$

Adapun pengertian hukum kewarisan dalam Kompilasi Hukum Islam (KHI) adalah hukum yang mengatur tentang pemindahan hak pemilikan harta peninggalan (tirkah) pewaris, menentukan siapa-siapa yang berhak menjadi ahli waris dan berapa bagian-bagiannya masing-masing. ${ }^{6}$ Dalam hukum kewarisan Islam, pembagian harta peninggalan harus diberikan kepada para ahli waris sesuai dengan ketentuan yang telah ditetapkan dalam Al-Qur'an.

Hukum kewarisan menurut Islam disebut dengan ilmu farâid, dalam istilah bahasa, adalah takdir (qadar) atau ketentuan, dan dalam istilah shara' adalah bagian-bagian yang ditentukan bagi ahli waris. Dengan demikian farâid adalah bagian ahli waris yang telah ditentukan besar kecil pembagian oleh shara.? Azhar Basyir menyatakan bahwa ahli waris dapat digolongkan menjadi tiga berdasarkan dari segi hak mereka atas harta warisan, yaitu ahli waris dhawil furûd, 'asâbah dan dhawil arhâm.

\footnotetext{
${ }^{3}$ Muhammad Shahrur, Al-Kitab wa Al-Qur'an: Qira'ab Mu'asyirah, (Dimasq: Dar al-Ahali li alTiba'ah, 1991), 579

4 Muhammad Ali Ash-Shabuni, Hukum Warisan dalam Syariat Islam, (Bandung: CV. Diponegaoro, 1988), 40.

${ }_{5}^{5}$ Ahmad Rofiq, Hukum Islam di Indonesia, (Jakarta: Raja Grafindo Persada, 2000), 35.

${ }^{6}$ Kompilasi Hukum Islam (KHI) Inpres No. 1 Tahun 1991 Pasal 171 (a).

${ }^{7}$ Fatchur Rahman, Ilmu Waris, cet. Ke-2, (Bandung: Penerbit al-Maarif, 1982), 32.
} 
Dhawil furûd merupakan golongan ahli waris yang bagian haknya tertentu, yaitu $2 / 3,1 / 2,1 / 3,1 / 4,1 / 6$ dan $1 / 8$. 'Asâbah adalah golongan ahli waris yang bagian haknya tidak tertentu, tetapi akan menerima seluruh harta warisan jika tidak ada ahli waris dhawil furûd. Apabila ada ahli waris dhawil furûd, maka ahli waris asâbah hanya berhak atas harta yang tersisa dan jika ternyata tidak ada sisa harta sama sekali, maka ahli waris asâbah tidak mendapatkan bagian apapun. Adapun dhawil arbâm merupakan golongan ahli waris yang haknya atas harta warisan disebabkan oleh hubungan kerabat dengan pewaris. Dhawil arbâm tetapi tidak termasuk golongan dhawil furûd dan asâbah. ${ }^{8}$

\section{Pembagian Harta Warisan}

Islam memandang harta sebagai jalan menuju ketakwaan. Banyak cara yang dianjurkan Islam untuk memperolehnya, yaitu dengan cara berniaga, beternak, dll. Dengan harta tersebut, Islam menganjurkan untuk mendistribusikannya secara merata. Itu sebabnya Islam mengatur segala hal yang berkaitan dengan harta, zakat, infak, sedekah, hibah, wasiat, dan wakaf. Hal ini menunjukkan, bahwa harta tidak hanya diperuntukkan bagi keturunan tetapi bagi umat manusia secara luas. Hal ini menyiratkan bahwa kemanfaatan harta menurut Islam bersifat luas. Harta tidak hanya diperuntukkan untuk anak keturunan, tetapi untuk masyarakat dan jihad di jalan Allah.

Dalam hal pembagian harta warisan, Islam juga mengatur jumlah golongan ahli waris secara luas, sebab ahli waris tidak terbatas hanya keluarga yang se-nasab tetapi juga di antara keluarga yang ikatannya timbul akibat tali perkawinan atau agama, seperti istri, orangtua, dan saudara kandung. Hal ini menunjukkan bahwa nilai sosialitas Islam selalu menyebar luas sehingga pemanfaatan harta warisan dapat merata, meskipun kemudian harta terbagi-bagi dalam jumlah yang kecil.

Implikasi logis dari adanya ahli waris yang meluas adalah semangat Islam yang menganjurkan untuk bekerja keras dan beribadah segiatgiatnya, sehingga akan terkumpul harta sebanyak-banyaknya, agar distribusi harta warisan bisa meluas.

Dalam Islam, hukum waris mempunyai kedudukan yang sangat penting dan diatur secara jelas juga rinci. Hal ini dikarenakan masalah pewarisan pasti dialami setiap orang. Karena hukum waris ini bersangkutan dengan masalah harta benda, maka diatur secara tegas dan

\footnotetext{
8 Ahmad Azhar Basyir, 1982, Hukum Waris Islam, (Yogyakarta: Fakultas Ekonomi UII), 2427.
} 
jelas agar tidak berpotensi menjadi sengketa. Hukum kewarisan Islam membedakan besar kecil bagian para ahli waris yang disesuaikan dengan kebutuhan hidup sehari-hari. Bagian-bagian tertentu bagi para ahli waris yang sudah ditentukan tersebut termasuk hal yang sifatnya ta'abbudî̀ yang wajib dilaksanakan. Oleh sebab itu, telah menjadi ketetapan sebagaimana dinyatakan dalam Al-Qur'an surat an-Nisa' ayat 11, 12, dan 13.

Ayat tersebut sangat jelas dan tegas. Al-Qur'an menggunakan

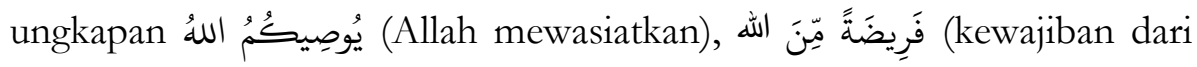

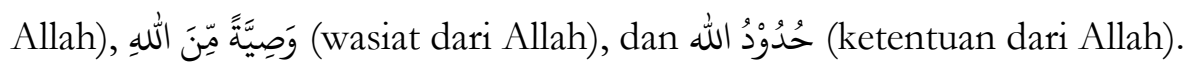

Golongan yang berhak sebagai ahli waris menurut hukum Islam adalah anak lelaki, anak perempuan, suami, isteri, ibu, ayah, saudara lakilaki, saudara perempuan, kakek, nenek, cucu laki-laki dan cucu perempuan. Adapun bagian yang diterima oleh ahli waris, para imam madhab sepakat atas bagian-bagian yang ditentukan dalam Al-Qur'an, yaitu: seperdua (nisf), seperempat, (rub), seperdelapan (thumun), dua pertiga (thuluthân), sepertiga (thuluth) dan seperenam (sudus). Selain itu hanya ijma' belaka.' Dimana pada setiap pembagiannya terdapat rasio perbandingan (2:1) antara yang diperoleh ahli waris laki-laki dan ahli waris perempuan. Rasio perbandingan 2:1 tidak hanya berlaku antara anak laki-laki dan perempuan, melainkan juga berlaku antara suami isteri, antara bapak-ibu serta antara saudara lelaki dan saudara perempuan.

\section{The Theory of Limit Muhammad Syahrur}

Keberadaan hukum kewarisan Islam direpresentasikan dalam teksteks yang rinci dan sistematis. Namun seiring dengan perkembangan zaman yang semakin modern, muncullah berbagai pemikiran-pemikiran modern yang didasarkan pada ilmu pengetahuan, yang selanjutnya memunculkan perbedaan pendapat dalam memahami berbagai ilmu, seperti halnya perkembangan dalam ilmu kewarisan Islam, yang kemudian memunculkan analisis gender yang berusaha untuk menyetarakan pembagian harta warisan antara laki-laki dan perempuan, karena menurut mereka pembagian waris 2:1 tidak mencerminkan keadilan. $^{10}$

Muhammad Syahrur, seorang intelektual asal Damaskus, Syria, mengembangkan teori yang dikenal dengan The Theory Of Limit (nazâriyat

\footnotetext{
9 Syaikh al-'Allamah Muhammad bin 'Abdurrahman ad-Dimasyqi, Fiqih Empat Madhab, terj. Abdullah Zaki Alkaf, (Bandung: Hasyimi, 2010), 322.

10 Abu Hamzah, Relevansi Hukum Waris Islam: Bias Isu Gender, Egalitarianisme, Pluralisme dan HAM, (Jakarta: As-Sunah, 2005), 50.
} 
al-hudûd/teori limit). Pemikiran Syahrur ini berangkat dari kegagalan masyarakat dalam mewujudkan "modernisasi", dan adanya penggunaan produk penafsiran hukum masa lalu untuk menghukumi persoalanpersoalan kekinian, yang menyebabkan kemandulan pemikiran Islam. Oleh karena itu Syahrur menawarkan sebuah metode baru dalam memahami hukum Islam yaitu dengan kembali kepada teks asli yang diwahyukan kepada Nabi SAW menggunakan apa yang disebut Syahrur sebagi "pemahaman baru" dalam memahami pesan-pesan Allah SWT ${ }^{11}$, metode baru tersebut seperti analisis kebahasaan, matematika analisis, dan penafsiran hermeneutik.

Menurut Syahrur, pembagian harta warisan jika mengacu pada ayatayat waris ternyata hingga kini masih menyisakan problematika yang belum terpecahkan ${ }^{12}$ seperti pembagian 2:1 antara laki-laki dan perempuan, problematika penambahan dan pengurangan prosentase harta warisan atau aul dan radd serta pihak-pihak yang tidak seharusnya mendapatkan bagian harta warisan, mengutamakan waris daripada wasiat, dan seterusnya. ${ }^{13}$ Menurut Syahrur, undang-undang kewarisan sudah saatnya diubah. ${ }^{14}$

Syahrur menggunakan berbagai metode dalam mengkaji hukum kewarisan Islam, seperti menggunakan teori linguistic atau kebahasaan dan teori matematika dengan merujuk kepada teori matematika analisis Newton yaitu ilmu yang menjelaskan hubungan antara variabel pengikut dan peubahnya, dengan metode matematika analisis, Syahrur merumuskan batas-batas hukum Allah yang di istilahkan dengan the theory of limit/teori limit/teori batas.

Adapun teori limit yang dirumuskan Syahrur mempunyai enam tipologi, yaitu:

Pertama, halah al-hadd al-a'la (posisi batas maksimal).

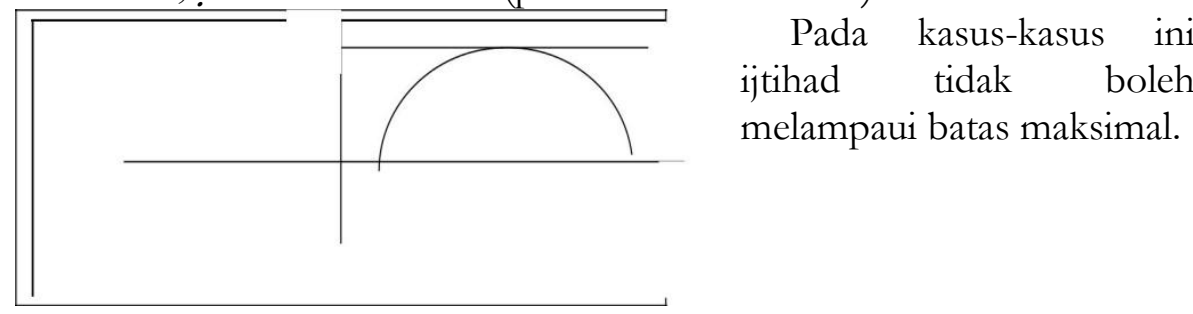

\footnotetext{
11 M. In'am Esha, Pemikiran Islam Kontemporer, (Yogyakarta: Jendela, 2003), 299-301.

12 Muhammad Syahrur, Metodolgi Fiqih Islam Kontemporer, terj. Sahiron Syamsudin, Jakarta: eLSAQ Press, 2004), 149.

${ }_{13}$ Muhammad Syahrur, Metodolgi Fiqih Islam Kontemporer, 342.

${ }^{14}$ Muhammad Syahrur, Metodolgi Fiqih Islam Kontemporer, 419.
} 
Kedua, halah al-hadd al-adna (posisi batas minimal).

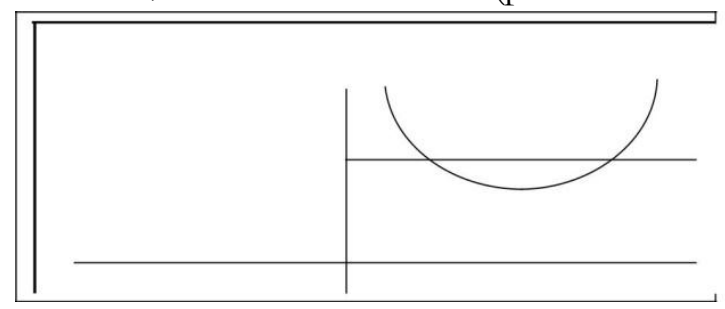

Pada kasus-kasus ini ijtihad tidak boleh melampaui batas minimal.

Ketiga, halah al-hadd al-adna wa al-hadd al-a'la ma'an (batas minimal dan batas maksimal bersamaan).

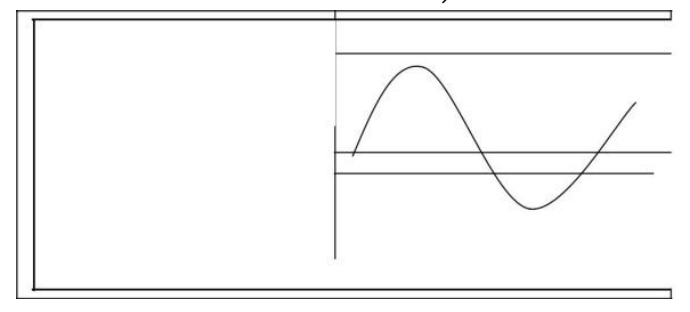

Ijtihad bisa secara leluasa dalam kasus-kasus ini selama tidak melampaui batas minimal dan batas maksima.

Keempat, halah al-hadd al-adna wa al-hadd al-a'la ma'an fi nuqtah wahidah (batas minimal dan batas maksimal berada dalam satu titik secara bersamaan). Karena batas maksimal dan batas minimal berada dalam satu titik, maka dalam kasus ini ijtihad tidak berlaku untuk mengurangi dari batas minimal atau batas maksimal.

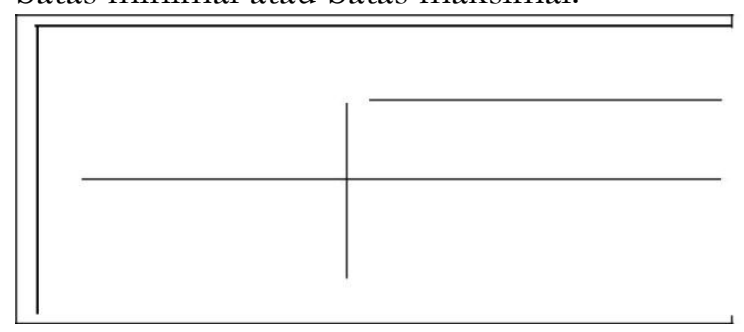

Kelima, halah al-hadd al-a'la bi kha muqarib li mustaqim duna lamas bi albadd (posisi batas maksimal cenderung mendekat, tanpa bersentuhan).

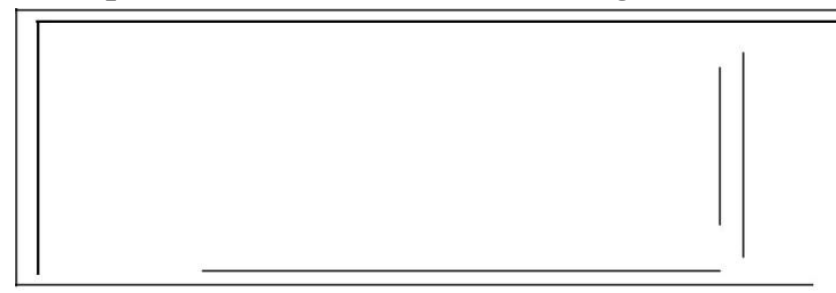

Keenam, halahal-hadd al-a'la mujaban wa al-hadd al-adna saliban (posisi batas maksimal bersifat positif, sedangkan batas minimal bersifat negatif). 


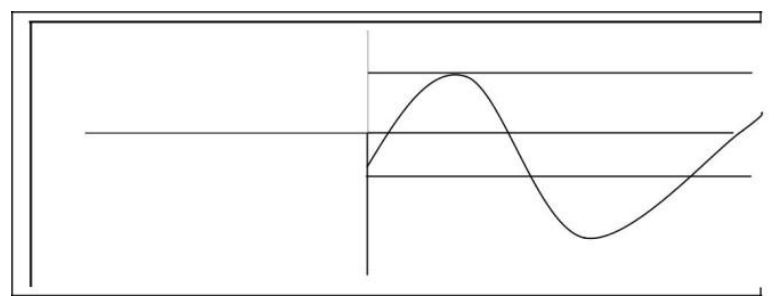

Adapun teori Limit atau Batas yang dikemukakan Syahrur, yang berkaitan dengan hukum kewarisan Islam adalah teori tentang ketentuan hukum yang memiliki batas atas dan batas bawah sekaligus (balatu al-hadd al-adna wa al-hadd al-a'la ma'an), yaitu QS. An-Nisa' ayat 11-14, 176). ${ }^{15}$

\section{Keadilan Gender dalam Pembagian Waris Islam dalam Perspektif Muhammad Syahrur}

Secara normatif, Al-Qur'an telah menegaskan laki-laki dan perempuan sebagai dua mahluk yang setara, seperti dalam masalah kewarisan yang kedua-duanya berhak untuk mendapat bagian harta waris. Hal yang paling menonjol menyangkut hukum kewarisan Islam adalah pembahasan tentang keadilan, dimana hak sama-sama dan saling mewarisi antara laki-laki dan perempuan serta perbandingan 2:1 (baca 2 banding 1) antara porsi laki-laki dan perempuan.

Sebagaimana kita ketahui, bahwa keadilan merupakan salah satu asas (doktrin) dalam hukum waris Islam. Asas keadilan dalam hukum kewarisan Islam mengandung pengertian bahwa harus ada keseimbangan antara hak yang diperoleh dan harta warisan dengan kewajiban atau beban kehidupan yang harus ditanggungnya atau ditunaikannya di antara para ahli waris, karena itu arti keadilan dalam hukum waris Islam bukan diukur dari kesamaan tingkatan antara ahli waris, tetapi ditentukan berdasarkan besar-kecilnya beban atau tanggung jawab diembankan kepada mereka, ditinjau dari keumuman keadaan atau kehidupan manusia.

Pembagian kewarisan yang menggunakan porsi 2:1 inilah yang sering kali dipertanyakan, digugat, atau bahkan dihujat oleh sebagian pihak yang tidak puas, termasuk dari kalangan internal orang-orang Islam sendiri, sehingga memunculkan argumentasi untuk menekan supaya para pakar hukum Islam menyamaratakan pembagian kewarisan antara anak laki-laki dan anak perempuan, di samping penyamarataan antara bagian suami dengan bagian istri. Menurut mereka, konsep keadilan itu adalah mendapatkan hak yang sama dan jumlah yang sama, yaitu 1:1. Jika

${ }^{15}$ Muhammad Syahrur, Prinsip dan Dasar Hermeneutika Al-Qur'an Kontemporer, 457. 
merujuk pada surat an-Nisa' ayat 11-13, bahwa kalimat فيُوِيكُمُ اللهُ فيف أَوَكَدِكُ (Allah mewasiatkan kepada kamu tentang hal jpembagian harta kewarisan]). Wasiat, yang secara literal artinya pesan. Salah seorang tokoh ulama Syiah Imamiyah abad VI Hijriyah, Al-Thabrasi, menafsirkan penggalan ayat ini, bahwa Allah memerintahkan dan memfardukan atas kamu wasiat, mengingat wasiat dari Allah itu adalah perintah dan keharusan ('amr wa fard) yang menunjukkan itu. ${ }^{16}$ Dari sini dapat diketahui, bahwa sebagian ulama menafsirkan penggalan ayat ini dengan tafsiran bahwa Allah lebih menyayangi seseorang dibandingkan kasih sayang orangtua kepada anaknya sendiri, tatkala Allah mewasiati kedua orang tua terkait dengan hak-hak warisan.

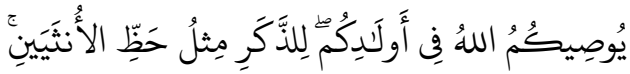

Artinya: "Allah mensyari'atkan bagimu tentang (pembagian pusaka untuk) anak-anakmu. Yaitu: bahagian seorang anak lelaki sama dengan bagabian dua orang anak perempuan."

Dalam tafsir Ibnu Katsir, dijelaskan bahwa Allah memerintahkan kalian untuk berbuat adil. Dulu, orang jahiliyah memberikan seluruh harta warisan hanya untuk laki-laki, tidak untuk perempuan. Maka Allah memerintahkan kesamaan di antara mereka dalam hal sama-sama menjadi ahli waris, dan membedakan bagian yang diperoleh di antara dua jenis tersebut, di mana bagian laki-laki sama dengan dua bagian perempuan. Hal ini disebabkan karena laki-laki bertanggung jawab atas nafkah, kebutuhan, serta beban perdagangan, juga usaha dan resiko tanggungjawab. Maka tepat jika dia diberikan bagian dua kali lipat dari pada bagian kaum wanita. Hal ini menunjukkan bahwa Allah lebih sayang kepada mereka daripada diri mereka sendiri.

Sebagaimana disebutkan dalam hadis shahih, bahwa Nabi pernah melihat seorang tawanan wanita yang terpisah dari anknya. Ia berkeliling mencari-cari anaknya. Ketika ia menemukanya dari salah seorang tawanan, maka ia pun mengambilnya, mendekapnya dan menyusukannya. Rasulullah bertanya kepada sahabatnya:

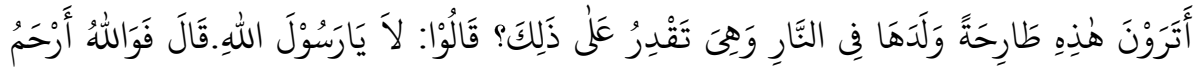

بِعِبَادِهِ مِنْ هُذِهِ بِوَلَدِهَا

Artinya: "Apakah kalian mengira bahwa wanita itu akan tega membuang anaknya ke dalam api padahal ia mampu melakukannya? Mereka

16 Abu 'Ali al-Fadhl ibn al-Hasan al-Thabrasi, Majma' al-Bayan fî Tafsir Al-Qur'an, Juz III, (Beirut: Dar al-Fikr, t.t.), 23-24. 
menjawab: 'Tidak ya Rasulullab!' Belian bersabda: Demi Allah, sesunggubnya Allah lebih penyayang kepada hamba-hambaNya daripada wanita itu kepada anaknya., 17

Ditinjau dari segi jumlah bagian saat menerima hak, memang terdapat ketidaksamaan. Akan tetapi hal tersebut bukan berarti tidak adil, karena keadilan dalam pandangan Islam tidak hanya diukur dengan jumlah yang didapat saat menerima hak waris tetapi juga dikaitkan kepada kegunaan dan kebutuhan. Karena secara umum pria membutuhkan lebih banyak materi dibandingkan dengan wanita. Hal tersebut dikarenakan pria dalam ajaran Islam memikul kewajiban ganda yaitu untuk dirinya sendiri dan terhadap keluarganya termasuk para wanita; sebagaimana dijelaskan Allah dalam surat an-Nisa' ayat $34 .^{18}$

Perbedaan porsi tersebut tidak disebabkan persoalan gender, melainkan atas perbedaan tugas dan tanggung jawab yang dibebankan kepada laki- laki lebih besar dibandingkan dengan yang dibebankan kepada perempuan dalam konteks masyarakat Islam, sesuai teori standar konvensional yang menyebutkan: "Semakin besar dan berat beban yang dipikul seorang laki-laki, maka semakin besar pula bak yang akan diperolehnya", disebabkan biaya yang harus dikeluarkannya untuk mengemban tanggung jawab dimaksud lebih besar.

Berkaitan dengan teori limit (budud) yang digunakan Syahrur dalam membaca ayat-ayat waris, Syahrur mengacu pada pengertian batas-batas ketentuan Allah yang tidak boleh dilanggar, tapi didalamnya terdapat wilayah ijtihat yang bersifat dinamis, fleksibel, dan elastis.

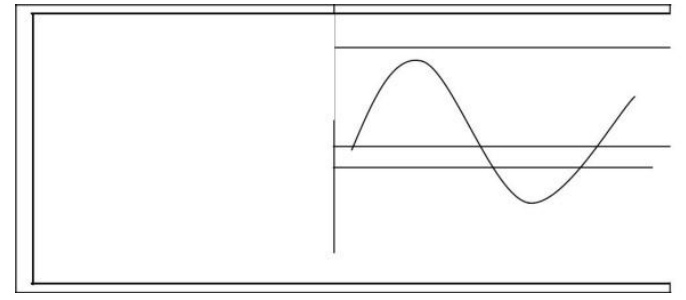

Syahrur menandaskan bahwa jalan lurus yang telah disediakan Tuhan bagi manusia agar mereka dapat bergerak sepanjang jalan lengkung di dalam teori batas Tuhan, sesuai dengan hukum manusia yang diperkenankan di antara batas-batas (budud) bahwa Al-Qur'an telah menetapkan seluruh tindakan manusia dan fenomena alam. Karena itu, dia menegaskan bahwa variasi hukuman yang secara rinci disebut dalam

\footnotetext{
${ }^{17}$ Lihat Shahih Muslim Jilid 6, hadis nomor 2109.

18 Maryati Bachtiar, Hukum Waris Islam Dipandang Dari Perspektif Hukum Berkeadilan Gender, Jurnal Hukum Volume 3 No.1.
} 
Al-Qur'an menandaskan batas tertinggi, bukan menggambarkan hukuman yang mutlak.

Syahrur merumuskan teori hududnya berangkat dari Q.S. an-Nisa: 13 yang terkait dengan pembagian waris. Pada ayat 13, terdapat kalimat تِنكَ

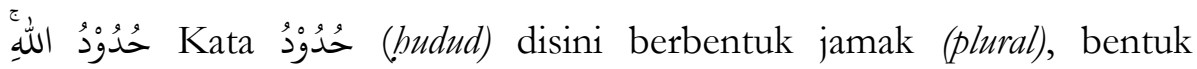
mufrodnya حد artinya batas (limit). Pemakaian bentuk plural di sini menandakan bahwa حد yang ditentukan oleh Allah berjumlah banyak, dan manusia memiliki keleluasaan untuk memilih batasan-batasan tersebut sesuai dengan tuntutan dan situasi dan kondisi yang melingkupinya. Selama masih berada dalam koridor batasan tersebut, manusia tidak menanggung beban dosa. Pelanggaran hukum Tuhan terjadi jika manusia melampaui batasan-batasan tersebut. ${ }^{19}$

Menurut Shahrur, ayat ini secara eksplisit menyebutkan bahwa masalah pembagian waris merupakan salah satu batasan dari sekian batasan hukum syariat yang ditentukan oleh Allah. Redaksi تِلَكَ حُدُوْدُ اللَفِ merujuk pada penjelasan ayat 11-12, dan pada saat yang sama juga menegaskan bahwa budud batasan hukum yang dimaksud berasal dari Allah.

Sehingga menurut Syahrur, hukum tidak boleh bersifat "tunggal" dengan satu pemahaman dan prespektif. Hukum Tuhan harus sesuai dengan kecenderungan manusia yang selalu berubah, maju, dan berkembang. Maka dalam Al-Qur'an akan selalu dijumpai bahwa syari'at hanya menentukan batasan-batasan (!hudud) saja, ada yang berupa batasan maksimal (al-had al-a'la) atau batasan minimal (al-bad al-adna) maupun variasi keduanya. Ajaran syariat yang disampaikan kepada Rasullah bersifat hududiyah, berbeda dengan syariat para rasul yang disampaikan sebelumnya yang a'iniyyah.

Syahrur menyatakan bahwa Allah SWT telah menetapkan konsepkonsep hukum yang maksimum dan yang minimum, al-istiqamah (straightness) dan al-hanifiyyah (curvature), sedangkan ijtihad manusia bergerak dalam dua batasan tersebut. Dalam batas-batas hukum ini, masyarakat manusia tidak hanya bebas, tetapi diwajibkan untuk mengembangkan dan mengadopsi hukum mereka menurut kesepakatan dan keadaan sosial politik masyarakat mereka.

19 Buranuddin, Artikulasi Teori Batas (Nazariyyah al-Hudud) Muhammad Shahrur Dalam Pengembangan Epistemologi Islam Di Indonesia, Editor, Sohiron Syamsuddin, dkk, Hermeneutika Al-Qur'an Marhab Yogya, (Yogyakarta: Islamika, 2003), 152. 
Pada QS. An-Nisa' ayat 11 menjelaskan bahwa bagian laki-laki dua kali lipat perempuan. Dalam konteks ini Syahrur menjelaskan bahwa lakilaki adalah batas maksimal dan tidak bisa ditambah lagi, sementara perempuan adalah batas minimal, jadi dalam kondisi tertentu seorang perempuan berpotensi mempunyai bagian lebih.

Dalam karyanya yang sangat kontroversial, al-Kitab wa Al-Qur'an: Qira'ah Muasyirah, Syahrur menegaskan bahwa teori limit merupakan salah satu pendekatan dalam berjihad. Hal ini digunakan untuk mengkaji ayat-ayat mubkamât (ayat-ayat yang berisi pesan hukum) dalam Al-Qur'an. Menurut Wael B Hallaq, teori limit Syahrur telah mengatasi kebuntuan epistimologis yang menimpa karya-karya sebelumnya.

Adapun kontribusi yang diberikan Syahrur dengan teori batas yang digagasnya dalam pengayaan fiqih, setidaknya ada empat, yaitu:

Pertama, dengan teori limit, Syahrur telah berhasil melakukan pergeseran paradigma (paradigm shift) yang sangat fundamental di bidang fiqih. Selama ini pengertian hudud dipahami para ahli fiqih secara rigid sebagai ayat-ayat dan hadits-hadits yang berisi ketentuan sanksi hukum (al-uquibad) yang tidak boleh ditambah atau dikurangi dari ketentuan termaktub, namun dengan teori limit yang ditawarkan Syahrur cenderung bersifat dinamis-kontektual.

Kedua, teori limit Syahrur menawarkan ketentuan batas maksimum (albadd al-adna) dan batas minimun (al-hadd al-a'la) dalam menjalankan hukum-hukum Allah. Artinya, hukum-hukum Allah diposisikan bersifat elastis, sepanjang berada diantara batas maksimum dan batas minimum yang telah ditentukan. Wilayah ijtihad manusia, menurut Syahrur berada diantara batas minimum dan maksimum tadi. Selagi ijtihat masih berada dalam wilayah budûdullah (batas-batas hukum Allah), maka dia tidak dapat dianggap keluar dari hukum Allah. Sebagai contoh, dalam waris, ketentuan pembagian 2:1 antara laki-laki dan perempuan, dimana dua bagian merupakan batas maksimum bagi laki-laki dan satu adalah batas minimum bagi anak perempuan.

Ketiga, dengan teori limitnya, Syahrur telah melakukan dekontruksi dan rekontruksi terhadap metodologi ijtihad hukum, utamanya terhadap ayat-ayat budud yang selama ini diklaim sebagai ayat-ayat muhkamat yang bersifat pasti dan hanya mengandung penafsiran tunggal. Bagi Syahrur, ayat-ayat muhkamat bahkan dapat dipahami secara pluralistik, sebab makna suatu ayat itu dapat berkembang, tidak harus sesuai dengan makna (pengertian) ketika ayat itu turun, tetapi penafsiran sebuah ayat sesungguhnya bersifat relatif dan nisbi, sesuai dengan perkembangan zaman. Selain itu, melalui teori limit-ny, Syahrur ingin melakukan 
pembacaan ayat-ayat muhkamat secara produktif dan prospektif (qirâ'ah muntijah) bukan pembacaan repetitive dan restrospektif (qirâ'ah mutakarrirah).

Keempat, dengan teori limit, Syahrur ingin membuktikan bahwa ajaran Islam benar-benar ajaran yang relevan untuk tiap ruang dan waktu. Syahrur berasumsi, kelebihan risalah Islam adalah bahwa di dalamnya terkandung dua aspek gerak, yaitu gerak konstan (istiqâmah) serta gerak dinamis dan lentur (hanifiyyah), sehingga membuat Islam sâlị li kulli zamân wa makân.

\section{Kesimpulan}

Gugatan terhadap pembagian waris 2:1 yang banyak dikemukakan oleh aktivis gender atau yang lainnya terkesan berlebihan dan kurang tepat. Dimana sebagian mereka mengatakan hukumnya relevan dengan masa lalu dan tidak relevan dengan masa kini dan yang akan datang. Menurut hemat penulis, untuk menerapkan konsep 1:1 seperti yang diinginkan oleh penggugatnya, banyak hal yang perlu dipertimbangkan. Baik dari segi dalil aqli (kontekstualis), dan lebih-lebih dari sisi dalil naqli (tekstualis), tentu dengan sama-sama menggunakan argumentasi yang bersifat ilmiah-akademik.

Dalam The Theory Of Limit/Teori Batas yang digagas oleh Syahrur, terdapat pengertian batas-batas ketentuan Allah yang tidak boleh dilanggar, tetapi di dalamnya terdapat wilayah ijtihad yang bersifat fleksibel. Menurutnya, QS. An-Nisa' ayat 11 yang menjelaskan bagian laki-laki dua kali lipat perempuan adalah batas maksimal dan tidak bisa ditambah lagi, sementara perempuan adalah batas minimal, jadi dalam kondisi tertentu seorang perempuan berpotensi mempunyai bagian lebih. Teori Limit yang dikemukakannya ini bermaksud untuk menyatakan bahwa ayat-ayat Al-Qur'an, senantiasa relevan pada setiap situasi dan kondisi, dan Islam merupakan agama terakhir dan bersifat universal yang ditujukan kepada seluruh umat manusia (sâlịh li kulli zamân wa makân).

Secara filosofis, hukum kewarisan Islam dalam pembagian waris merefleksikan tanggungjawab laki-laki yang dua kali lebih besar dari perempuan, mengingat laki-laki wajib bertanggung jawab atas istri dan anak-anaknya. Pembagian waris 2:1 ini pada akhirnya juga akan disalurkan untuk istri dan anak-anak yang menjadi tanggung jawabnya, bukan untuk dirinya sendiri. 


\section{Daftar Pustaka}

Anderson, J.N.D. Hukum Islam di Dunia Modern. Yogyakarta: Tiara Wacana, 1994.

Bachtiar, Maryati. "Hukum Waris Islam Dipandang Dari Perspektif Hukum Berkeadilan Gender" Jurnal Hukum, Volume 3 No.1.

Basyir, Ahmad Azhar. Hukum Waris Islam. Yogyakarta: Fakultas Ekonomi UII, 1982.

Buranuddin. Artikulasi Teori Batas (Nazariyyah al-Hudud) Muhammad Shahrur Dalam Pengembangan Epistemologi Islam Di Indonesia, Editor, Sohiron Syamsuddin, dkk, Hermeneutika Al-Qur'an Marbab Yogya. Yogyakarta: Islamika, 2003.

Dimasyqi (al), Syaikh al-'Allamah Muhammad bin 'Abdurrahman. Fiqih Empat Madhab, terj. Abdullah Zaki Alkaf. Bandung: Hasyimi, 2010.

Esha, M. In'am. Pemikiran Islam Kontemporer. Yogyakarta: Jendela, 2003.

Hamzah, Abu. Relevansi Hukum Waris Islam: Bias Isu Gender,

Egalitarianisme, Pluralisme dan HAM. Jakarta: As-Sunah, 2005.

Kompilasi Hukum Islam (KHI) Inpres No. 1 Tahun 1991.

Mubarakfuri (al), Syaikh Shafiyyur Rahman. Shabih Tafsir Ibnu Katsir, terj.

Abu Ihsan al-Atsari. Bogor: Pustaka Ibnu Katsir, 2006.

Rahman, Fatchur. Ilmu Waris. Bandung: Penerbit al-Maarif, 1982. Cet. II.

Rofiq, Ahmad. Hukum Islam di Indonesia. Jakarta: Raja Grafindo Persada, 2000.

Said, Hasani Ahmad. "Dekonstruksi Syariah: Menggagas Hukum Waris Perspektif Jender" Jurnal Al-'Adalah, Vol. XI, No. 1 Januari 2013.

Sarmadi, A. Sukris. Transendensi Keadilan Hukum Waris Islam Transformatif. Jakarta: Raja Grafindo Persada, 1997.

Shabuni (al), Muhammad Ali. Hukum Warisan dalam Syariat Islam. Bandung: CV. Diponegaoro, 1988.

Shahrur, Muhammad. Al-Kitab wa Al-Qur'an: Qira'ah Mu'asyirah. Dimasq: Dar al-Ahali li al-Tiba'ah, 1991.

- Metodolgi Fiqih Islam Kontemporer, terj. Sahiron Syamsudin. Jakarta: eLSAQ Press, 2004.

Thabrasi (al), Abu 'Ali al-Fadhl ibn al-Hasan. Majma' al-Bayan fì Tafsir AlQur'an. Beirut: Dar al-Fikr, t.th. Vol. III.

Tim Penyusun. Ensiklopedi Hukum Islam. Jakarta: Ikhtiar Baru-Van Hoeve, 1997. Vol. II.

Umar, Nasarudin. Argumen Kesetaraan Jender. Jakarta: Paramadina, 2001. 